\title{
THE WRITTEN PRODUCTION OF ARGUMENTATIVE AND DISSERTATION TEXT: A DIDACTIC PROJECT BASED ON BAKHTIN'S PHILOSOPHY
}

\author{
A PRODUÇÃO ESCRITA DE TEXTO ARGUMENTATIVO-DISERTATIVO: \\ UM PROJETO DIDÁTICO BASEADO NA FILOSOFIA BAKHTINIANA
}

\section{LA PRODUCCIÓN ESCRITA DEL TEXTO ARGUMENTIVO-DISSERTATIVO: UN PROYECTO DIDÁCTICO BASADO EN LA FILOSOFÍA DE BAKHTIN}

Marcos Rogério Martins Costa ${ }^{1}$; Patrícia Margarida Farias Coelho ${ }^{2}$; Irene Garcia Medina ${ }^{3}$

\begin{abstract}
This article is characterized as a theoretical and practical research related to a project developed during the year 2015 in two schools, one public and the other private, in the city of Birigui, State of São Paulo, Brazil. The main goal of the study was to analyze the pedagogical project and the teachers' activities oriented towards the teaching and learning of argumentative and dissertation texts. The methodology used in this research comprised: (i) visiting both schools, (ii) producing a description of ongoing school practices, with special attention to the teaching of argumentative and dissertation texts, (iii) suggesting an activity to the teacher in order to improve this apprenticeship, (iv) implementing this activity and (v) analyzing obtained results. The theoretical framework used for this study was the Bakhtinian philosophy (BAKHTIN, 2013; 2006a; 2006b; 2006c; 2006d; 2010; 2013; VOLOSHINOV, 1986). This theoretical approach was chosen due to the importance of comprehension of the text not just as a set of words, phrases and paragraphs; but as a structure of significance, in which we encounter linguistic forms, ideologies and discursive stance. At last, the results show that the texts that were analyzed and produced during the carried out project supported in the students' development of argumentative skills, enhancing, this way, their capacity to argue and organize ideas in a formal communicative situation.
\end{abstract}

KEYWORDS: Argumentative and dissertation text. Teaching. Bakhtin's philosophy. Portuguese language. School.

\footnotetext{
${ }^{1}$ Mestre em Linguística - Semiótica e Linguística geral - Faculdade de Filosofia, Letras e Ciências Humanas da Universidade de São Paulo (FFLCH-USP). São Paulo, SP - Brasil. Professor de Ensino. Fundamental II e Médio Secretaria Municipal de Educação de São Paulo. São Paulo, SP - Brasil. E-mail: marcosrmcosta15@gmail.com 2 Doutora em Comunicação e Semiótica - Pontifícia Universidade Católica de São Paulo (PUC-SP). São Paulo, SP - Brasil. Professora permanente da Universidade Metodista de São Paulo. São Paulo, SP - Brasil E-mail: patriciafariascoelho@gmail.com

${ }^{3}$ Doutora em Relações Internacionais - Universidade de Viena - Viena (Áustria); Doutora em Marketing University of Nice Sophia Antipolis (UNS) - Nice (França). Professora titular de Marketing no Departamento de Gestão de Negócios - Universidade Caledônia de Glasgow (GCU) - Glasgow G4 OBA, Reino Unido. E-mail: irene.garcia2@gcu.ac.uk
}

Submetido em: 23/09/2016 - Aceito em: 01/05/2017

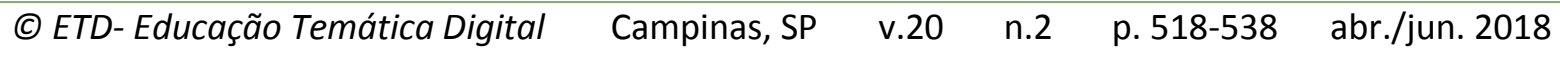




\section{RESUMO}

Este artigo é caracterizado como uma pesquisa teórica e prática relacionada a um projeto desenvolvido durante o ano de 2015 em duas escolas, uma pública e outra privada, na cidade de Birigui, no Estado de São Paulo, Brasil. O principal objetivo do estudo foi analisar o projeto educacional e as atividades dos professores orientadas ao ensino e aprendizagem de textos dissertativo-argumentativo. A metodologia utilizada na pesquisa consistiu em: (i) visitar as duas escolas, (ii) fornecer uma descrição das práticas escolares usadas, com especial atenção para o ensino de textos dissertativo-argumentativos, (iii) sugerir uma atividade aos professores para melhorar a aprendizagem desse tipo de texto, (iv) implementar essa atividade e (v) analisar os resultados obtidos. O referencial teórico utilizado para este estudo foi a filosofia bakhtiniana (BAKHTIN, 2013; 2006a; 2006b; 2006c; 2006d; 2010; 2013; VOLOSHINOV, 1986). Esta abordagem teórica foi escolhida devido a importância da compreensão do texto, não apenas como um conjunto de palavras, frases e parágrafos; mas como uma estrutura de significação, em que encontramos formas linguísticas, ideologias, bem como a postura discursiva. Finalmente, os resultados mostram que os textos analisados e produzidos durante o projeto executado ajudaram no desenvolvimento da habilidade argumentativa dos alunos, aumentando assim a sua capacidade de discutir e organizar ideias em uma situação comunicativa formal.

PALAVRAS-CHAVE: Texto argumentativo- dissertativo. Ensino. Filosofia bakhtiniana. Língua portuguesa. Escola.

\section{RESUMEN}

Este artículo se caracteriza por ser una investigación teórica y práctica relacionada con un proyecto desarrollado durante el año de 2015 en dos escuelas, una pública y la outra privada, en la ciudad de Birigui, en el Estado de São Paulo, en Brasil. El objetivo principal del estudio fue analizar el proyecto pedagógico y las actividades de los maestros orientadas hacia la enseñanza y el aprendizaje de disertaciones y textos argumentativos. La metodología utilizada en esta investigación consistió en: (i) visitar las dos escuelas, (ii) realizar una descripción de las prácticas escolares utilizadas, con especial atención a la enseñanza de los textos argumentativos y de disertación, (iii) sugerir una actividad a los maestros para mejorar el aprendizaje de este tipo de texto, (iv) implementar esta actividad y (v) analizar los resultados obtenidos. El marco teórico utilizado para este estudio fue la filosofía Bakhtiniana (BAKHTIN, 2013; 2006a; 2006b; 2006c; 2006d; 2010; 2013; VOLOSHINOV, 1986). Este enfoque teórico fue elegido debido a la importancia de la comprensión del texto no sólo como un conjunto de palabras, frases y párrafos; sino como una estructura de significado, en la que encontramos con formas linguísticas, ideologías y una postura discursiva. Finalmente, los resultados muestran que los textos analizados y producidos durante el proyecto ejecutado ayudaron en el desarrollo de la habilidad argumentativa de los alumnos, aumentando, así, su capacidad de discutir y organizar ideas en una situación comunicativa formal.

PALABRAS CLAVE: Textos argumentativo-disertativo. Enseñanza. Filosofía de Bakhtin. Lengua portuguesa. Escuela.

\section{INTRODUCTION}

Because of its simplicity and clarity, dialogue is a classic form of speech communication. Each rejoinder, regardless of how brief and abrupt, has a specific quality of completion that expresses a particular position of the speaker, to which one may respond or may assume, with respect to it, a responsive position. (BAKHTIN, 1986, p. 72).

Understanding the mechanism articulating the Brazilian Portuguese educational system and its role played in schools is not an easily performed task. What motivates the researcher to get out of the boundaries of the university and penetrate the schoolteachers' habitat is not idealism or a utopic conception of the swift change in the educational policies currently in effect. Instead, it is the need to comprehend teaching and learning conditions 
from the perspective of its methodological and practical execution, so that we can, then, (re)think our educational models.

In order to do that, the researcher must qualify his/her beliefs of what is and what should be a model school. Besides that, he/she needs to observe in practical terms the dialogues and tensions experienced in this environment among particular individuals, who are members of certain socioeconomic and historical groups. After that, the specialist must extract out of every event the remarkable peculiarities pertinent to a study of the community and its ideologies, which act in the paths of speech, asserting the positioning of its speakers ${ }^{4}$.

As Bakhtin (2006a, p. 289, free translation) proposes, one must conceive the enunciation as "a chain in discursive communication. It is the active positioning in this or that field of object and of meaning". We point out that our main purpose is not to make a comparative analysis between classrooms, or between schools. Our fundamental interest is to comprehend educational conditions in each school and, from this understanding, propose a didactic project focused on attending demands in teaching and learning, specifically when related to our object of study, the argumentative text inserted in the textual typology of argumentative dissertation.

We have selected texts of argumentative character because, according to Platin (1996), the argumentation acts upon human behavior, therefore, it permeates interests, the particularities of the target to be attained, the values employed in discourse, amongst other areas. Hence, we understand that, as we reason, we come to integrate the other, to participate in a dialogue with him/her. In that manner, the dialogic principle of language is fulfilled, in accordance to the Bakhtinian proposition:

Dialogue, in the narrow sense of the word, is, of course, only one of the forms - a very important form, to be sure - of verbal interaction. But dialogue can also be understood in a broader sense, meaning not only direct, face-to-face, vocalized verbal communication between persons, but also verbal communication of any type whatsoever (VOLOSHINOV, 1986, p. 95).

Assuming, then, that the relevance of associating the Bakhtinian studies to argumentative matters, this study is characterized as a theoretical and practical research derived from a project developed during the year 2015 in the context of schools pointed out in the following topic. We emphasize that our main goal was to analyze the pedagogical

\footnotetext{
${ }^{4}$ As explained by Ponzio (2010, p.9, free translation), the Russian word postupok, action, "contains the stem 'stup', which means 'step', the action in the form of a step, of initiative, movement, risky action, of taking a stand. It is in the sense of taking a stand that it is possible to perceive Bakhtin's philosophy. We stress that the philosopher's objective is to answer how it is possible to investigate, in a liable manner, the singularity (in Russian, edinstvennji) which constitutes and penetrates the human act without losing sight of its general character.
}

(C) ETD-Educação Temática Digital Campinas, SP $\quad$ v.20 $\quad$ n.2 $\quad$ p. 518-538 abr./jun. 2018 
project and the teacher's activities oriented towards teaching and learning of argumentative and dissertation texts, so that we could propose our own didactic project.

The methodology used in this research comprised: (i) visiting both schools, (ii) producing a description of ongoing school practices, with focus on the teaching of argumentative and dissertation texts, (iii) suggesting an activity to the teacher in order to improve this apprenticeship, (iv) implementing this activity and (v) analyzing obtained results.

The theoretical framework used for this study was the Bakhtinian philosophy (BAKHTIN, 2013; 2006a; 2006b; 2006c; 2006d; 2010; 2013; VOLOSHINOV, 1986). This theoretical approach was chosen due to the importance of comprehension of the text not just as an amalgamated set of words, phrases and paragraphs; but as a structure of significance, in which we encounter linguistic forms, ideologies and discursive stance (cf. BAKHTIN, 2006a).

Dealing with the work of Brazilian teachers, we face a series of questions and, most importantly, difficulties. Therefore, this article aims to present the results of a project which lends itself to aiding future investigators that, like us, lean themselves over the reality of Brazilian schools and also want to propose activities that orient improvement in the teaching and learning of Brazilian Portuguese, specifically in the production of argumentative texts.

We highlight that this article presents the results of an independent project developed by the authors, since 2013, entitled Theory and practice: a Bakhtinian perspective. The aim of this project was - and continues to be - to investigate the theoretical and pedagogical permeability of the concepts of Bakhtin's philosophy in the classroom. At each new stage of the project, new researchers are invited; as well, the results are published in scientific journals (cf. COSTA; COELHO, 2013; COELHO; COSTA, 2013).

We have chosen to approach Bakhtin's philosophy in Education for several reasons. Among them, we selected three. Firstly, the philosopher of language, Mikhail Bakhtin, became known and diffused in this field from 1980, being considered one of the currents that most influence the models of education in Brazil. Secondly, this theory is referenced in most of the official documents that regulate Basic Education in the national territory. Thirdly, Bakhtinian concepts influence the thematic and structural organization of the didactic materials of most educational systems in the country - for example, the notion of discourse genres. These are the main reasons that motivated this study and the project in which it belongs. Having exposed our analysis proposition, we now move to its description and put it into practice. 


\section{SCHOOLS A AND B: A SOCIAL AND HISTORICAL CONTEXT}

Penetrating the school and examining its bases, conflicts and discursive spheres in an adequate and coherent way are indispensable steps for the proposition of new pathways, as well as for the revision of the ones already trodden. With that in mind, we have executed the following project.

In 2015, we visited two schools in the countryside of the State of São Paulo, located $530 \mathrm{~km}$ away from the capital. Both of them are situated in the outskirts of the city, hosting students of very diverse profiles. One school (hereinafter School A) is public, and admits students from the $5^{\text {th }}$ year of Elementary School to the $3^{\text {rd }}$ year of High School (senior year), coming from nearby neighborhoods and rural areas. The other school (hereinafter School B) is private, and admits students from the $1^{\text {st }}$ year of Elementary School to the $3^{\text {rd }}$ year of High School, coming from several of the city's neighborhoods and even from adjacent cities ${ }^{5}$.

The period these schools have been operating is also different: School A was founded in 1993 and School B, in 2005. We observe, still, that School B belongs to an educational group operating since 1999, whose students sum more than 10.000 (counting schools and faculties) derived from more than 35 cities of the State of São Paulo. Such condition provides School B with a bigger physical and financial space, which reflects in its facilities and its performing policies in the market.

Concerning the internship in these institutions, we point out that we stayed 120 hours (h) in these centers, being $60 \mathrm{~h}$ in each educational institution. Out of these $60 \mathrm{~h}, 20 \mathrm{~h}$ were spent in observation, $10 \mathrm{~h}$ in the principal's office and $30 \mathrm{~h}$ in the intervention project.

As scope for our study, we have selected the $3^{\text {rd }}$ year of High School (henceforth $3^{\text {rd }}$ HS), last cycle for basic education in Brazil. We have worked, therefore, with two classrooms, one from School $A$ and the other from School B, designated henceforth as classroom $3^{\text {rd }} \mathrm{HS} \mathrm{A}$ and classroom $3^{\text {rd }} \mathrm{HS} \mathrm{B.}{ }^{6}$

\footnotetext{
${ }^{5}$ Here we label the schools and their classrooms, teachers, students and staff using an alphanumeric system, once we agreed with the institutions that we would maintain anonymity as a way of preserving the integrity of the participants in the field research. We draw attention, still, that all data here presented is official and was provided by the institutions themselves, as, for example, the information about the "High School National Exam" (ENEM) and the "Development Index for Education of the State of São Paulo" (IDESP). In addition, all participants from both schools signed the consent form, thus guaranteeing all necessary ethical procedures for the execution and subsequent disclosure of data from this study.

${ }^{6}$ We have selected the $3^{\text {rd }}$ HS because the Ministry of Education in Brazil, by means of the ordinance 2.941, has rendered the demand of mandatory essays in all the selection processes from higher education institutions. Therefore, all the students coming out of HS will inevitably have to produce an essay to continue their studies in the higher education level. Usually, the textual typology requested the very combination of argumentation and dissertation, which justifies the focus of this project on the $3^{\text {rd }} \mathrm{HS}$.
}

(C) ETD- Educação Temática Digital $\quad$ Campinas, SP $\quad$ v.20 $\quad$ n.2 $\quad$ p. 518-538 abr./jun. 2018 
Having placed the schools in time and space, we can say that, in this topic, we stress the general aspects and peculiarities of the visited school environment and of our research. In the next item, we will approach the subjective features, thus dialogical, which interfere in and constitute the teaching objects presented in these schools, with focus in the teaching of the argumentative and dissertation text. This because, as defended by Bakhtin (2006c, p.402), "hidden behind this contact [between texts] lies the contact between individuals and not between things (at the limit)". After comprehending this choice of route, we move forward on our journey.

\section{ONGOING SCHOOL PRACTICES: THE ARGUMENTATIVE AND DISSERTATION TEXT INSIDE THE CLASSROOM}

As a methodological and theoretical means to comprehend ongoing school practices in the visited schools, we have primarily opted to observe how the government's official organs in Brazil establish these practices in the school system. In order to do that, we searched support on the National Curricular Parameters (henceforth NCPs), in its high school version (BRASIL, 2000), and in the Curricular Orientation in Portuguese Language for High School (BRASIL, 2006). In a general way, we can infer on the governmental stance from reading the first paragraph in the NCPs:

High school in Brazil is changing. The consolidation of the democratic State, new technologies and the changes in the production of goods, services and knowledge demand that the school provides the students with integration to the contemporary world in the fundamental dimensions of citizenship and work. (BRASIL, 2000, p.4, emphasis added; free translation)

As we have pointed out in the highlighted excerpt, there is a purpose in the direction of the promotion of citizenship and work. One supplements the other. Thus, education and its structures need to maintain themselves alert to the fundamental dimensions which provide apparatus and support to the democratic State, that is, citizenship and work. This is confirmed by the words of the Russian philosopher Bakhtin (2006a, p.330, free translation):

\footnotetext{
All live, competent and impartial observation made of any position or any point of view always conserves its value and its meaning. The one-sidedness and the limitations of point of view (from the observer's position) can always be corrected, completed and transformed (enumerated) with the aid of the same observations carried out from other points of view. The poor points of view (lacking live and new observers) are infertile.
}

Hence, in accordance with the Russian researcher, we understand that the State's point of view is not unique, static and monologic. Unlike that, a dialogical relation allows an exchange between both parties: from the State to the school, as well as from the school to the State. Thus, these exchanges between State and school are not unilateral, once the school and the State have to interact and their perspectives and limitations have to be

(C) ETD-Educação Temática Digital Campinas, SP $\quad$ v.20 $\quad$ n.2 $\quad$ p. 518-538 abr./jun. 2018


corrected, completed and transformed, as above mentioned by Bakhtin (2006a). The existence of this dynamic permits us to agree with the definition on the action of teaching proposed by Freitas (1996, p. 173, free translation):

Educating is not to homogenize, to produce in large scale, but to produce singularities. To let surface the diversity of idiosyncrasies in the manners of being, of acting, of constructing: to permit the counter-word. Educating is to elevate the student to the position of author, to be the one to say his/her own word, to interact with the language, to penetrate into a live and real writing.

Still, accomplishing this exchange in an effective way demands work from the teacher that makes the dialogue between students and their object of study feasible. This interaction is made viable with the creation of public measures that provides support to this practice. In Brazil, that has actually taken place when the Bakhtinian theory was inserted in the epistemological framework of educational studies. As alleged by Barbosa (2001, p.91, free translation):

\begin{abstract}
In fact, the casting of genres as a teaching-learning object implies a change of perspective, of objectives, contents and methodology: instead of establishing practices and general goals which aim at the construction of capabilities, competences or the use of strategies, as it is usual in the curricular programs of Portuguese Language, we now deal with contents which are proper for teaching the genres of speech, around which the practices of comprehension and production of texts are organized.
\end{abstract}

Through this conception of these educational objects (that is, what to teach inside the classroom), the teacher can apply a methodology and an epistemology which allow a more responsive meditation over the condition of the production, circulation and reception of texts in the several spheres of human action. That is because one will be able to understand, based on Bakhtin (2006c, p.401), that "the text only comes to life when in contact with another text (context). Only from the perspective of this contact of texts emerges the light which illuminates retrospectively and prospectively, launching such text into the dialogue".

According to Bakhtin (2010), the action is responsive and responsible, because as we act, we take on a responsibility and we respond with our actions to the ones that preceded us and the ones that will succeed us. The way Bakhtin has found to elucidate the singularity of actions without degrading them into generalizations was the following: to understand that each act we do is defining our existence like a signature.

Bakhtinian philosophy embraces language as it is used in dialogue, thus, it is opposed to the lexical and finalized state of word. Coupled with a strong emphasis on the essential authorial relationship between participants, the responsive and responsible act is a way of being and of inhabiting the world. In other words, authorship is the mark of presence and, consequently, of existence of a person, who is never alone. One summons another, even in 
a monologue. Therefore, the concept of dialogism calls the notion of authorship and vice versa. We mark a presence and define our existence, when we position ourselves in the world. Knowing that no statement is the first or only one, we are always in dialogue, whether in the oral modality or in the written modality of the language. From this perspective, the production of school essays was reevaluated in its principle and its function in this study.

We need to refer to past studies to understand this textual typology. The essay was, until 1990, treated by the teachers as a means of verifying and evaluating learning in the student's grammar competences in the exercise and use of the language's written form. Using this approach, the social, cultural and historical functions, which interfere in the production of writing, were dismissed. Differently, the genres of speech proposition considers the enunciation as a concrete enunciate in its dialogical relations, which, in turn, assumes a responsive and responsible action from the speaker-, the Brazilian educational system and the community of teachers and students had to review their concepts of text and notions of grammar.

However, this change has not taken place in an effective and satisfactory manner. Up to this moment, we possess a vertical overview, once the State has proposed that the NCPs followed the Bakhtinian theory, but has not presented the necessary conditions for this theory to be enforced in the school environment in an efficient way. We point out that there were indeed several attempts from both parties, since the dialogue between school and State does exist. However, we cannot yet say that the execution has been fulfilled and the Bakhtinian studies were really inserted in the Brazilian educational context, as alleged by Rojo (2000).

The work we have performed in 2015 alongside the two schools is a testimony to this fact. They still maintained vestiges from the old model, that is, they understand the production of text as a means of evaluation and control of grammar rules and the use of the written language. However, there was, mainly among the younger teachers, the perception of theoretical change in the Brazilian pedagogical stance. This was also noteworthy in the system of workbooks adopted by both schools - both on the State of São Paulo's workbook, at School A, and the Dom Bosco's one, at School B - for they acknowledged, each one in its own manner, that the text constitutes dialogical relations with the context of production, circulation and reception.

In School A, teaching is generally anchored in didactic devices: chalk, board and workbooks. The teachers' didactic gestures were summarized in correcting exercises, reading activities and theoretical explanation, this last one being more prescriptive than descriptive of the language phenomenon. That way, the classes' content was transmitted, in fact, not being inserted in the students' context, so that they could interact with the language's mechanisms and its rules of grammar regulation.

(C) ETD- Educação Temática Digital $\quad$ Campinas, SP $\quad$ v.20 $\quad$ n.2 $\quad$ p. 518-538 abr./jun. 2018 
Now, in School B, teaching was supported by the board, chalk, workbooks and audiovisual media, like movies, video classes, PowerPoint presentations, etc. Thus, teachers had a broader dynamic in the school environment, so that the students could search for educational objects in different collections, printed as well as virtual. For that reason, contents were more diverse; nonetheless, evaluative processes privileged the educational objects mainly inserted in the workbooks' material, which narrowed the teachers' independent course of actions.

We then note that, in both schools, there are resources, professional personnel and different propositions, but they continued to reproduce the traditional pedagogy in which the text is maintained as being the means of evaluation for the language in written form. The text, considering the Bakhtinian philosophy, should be understood as a practice in the school environment and not only as a school content.

According to Schneuwly (2009), school has become an agency for inventing new applied genres. That is so because school injects objects to be taught into society, but there are knowledge objects and diverse practices in the everyday language that may cause paradox between what to teach and how to teach. These objects, ultimately, are not the equivalent to the ones found outside the school walls. Therefore, they are intimately associated with the practices in which they originate themselves, i.e., the school creates and teaches its own genres. Schneuwly (2009) proposes that these knowledge objects be taught in their own spheres of production, circulation and reception, maintaining the relation between speech genres and the teaching practices.

For that reason, the relationship among teacher, student and educational object is so complicated. The student belongs to a certain social sphere, with all its diversity. The teacher, inside of the school's politics, creates a pedagogical sphere with its own textual and discursive typologies. Finally, the educational object is not a reflection of the conditions that have caused itself to be inserted in the school's curriculum, but a refraction of the social, historical and cultural aspects that maintain it in this curriculum.

Thus, the difficulty found by schools and its members in putting the Bakhtinian philosophy into practice is this lack of comprehension that, inside the school, there are spheres of distinct human agency, which usually are not the same as the ones performed in contemporary society. For this reason, although School B resorts to new digital media with more frequency than School $A$, both continue to privilege the use of written production as a primary tool for evaluation.

Another interesting fact that we have observed in the strategy for the teaching of text production - specifically in its argumentative and dissertation form, which is the focus of this study -, is the lack of a theoretical distinction between the concepts in discursive 
typology and textual typology. Therefore, we consider this discrimination an essential one for a methodological improvement in the teaching of text production:

It is necessary [...] to discern textual typologies from discursive typologies. The former, in a general way, classify the texts based on its form, structure or function. Thus, we can talk about, for example, instructional texts - whose purpose is to instruct - or about humorous texts, or commercial ones - whose purposes are to entertain or sell/buy.

Likely, the textual typology you know best is the one based in the analysis of forms and structures, the one that sets apart texts into narrative, descriptive and dissertation (or argumentative and dissertation) text. [...] Now, the discursive typologies are linked to the social circumstances of production and circulation of discourse and, consequently, of the texts that aggregate these discourses.

Many of them divide the texts by spheres of production and circulation, mentioning discourses (or texts) related to journalism, science, literature, politics, pedagogy, etc. Others focus on the way of diffusing discourses and they will speak of authoritative, ludic, plastic, persuasive, polemic, polyphonic discourses, among others. Others still, will classify the discourses based on its themes, creating types such as: economic, police, medical, psychoanalytical discourse, etc. (BRAIT; ROJO 2003, p. 30-31, free translation)

Therefore, we can comprehend that the argumentative and dissertation text is a textual typology and, thus, in its teaching process, its argumentative function must be privileged. Hence, it is importance to relate the Bakhtinian theory to a more concerned perspective about the argumentative role of language, which strengthens the basic principle of dialogism and stylistic aspects. This is because, according to the very words of the Russian philosopher, "the grammatical forms cannot be studied if their stylistic meaning is not taken into account. When isolated from the semantic and stylistic aspects from language, grammar inevitably degenerates into scholasticism." (Bakhtin, 2013, p.23, free translation).

With this overview of the teaching practice in Brazil and specifically in the chosen schools in mind, we can understand part of the Brazilian educational system: from theory to practice. In the next topic, we will describe the didactic project performed by us and comment on its results. We emphasize that our commitment in this project was to observe both the stylistic aspects and the dialogical mechanisms and strategies present in the construction of the concrete enunciation so that we can, thereby, fulfill what is proposed on the NCPs under the aegis of the proposal for speech genres (BAKHTIN, 2006a).

\section{A DIDACTIC PROPOSAL FOR THE TEACHING OF ARGUMENTATIVE AND DISSERTATION TEXTS}

Following our methodology, we detail our suggestion for a teacher's activity, that is, our didactic project performed to improve the teaching of argumentative and dissertation texts in the visited schools. We highlight that the didactic strategy and the scheduled 
content were the same for both institutions. Thus, our main objectives within this project were to conceptualize and detail on appropriate discursive productions for the comprehension and, mainly, the construction of arguments in written texts. That is so because, as it is proposed by Bakhtin (2006a, p.371, free translation):

The enunciation (production of discourse) as a whole belongs to an entirely new field of communication (as a unit in this new field) [...]. This field is directed by a specific law and in order to be studied, it requires a special methodology and even, one can openly say, a special science (a scientific discipline)."

In that sense, we engage in the development of the capacity to select, organize and dispose of ideas and arguments inside of a textual typology, in our case, the argumentative and dissertation text. This textual typology enables the defense of a responsive stance inside of a polemic situation inserted into a specific context, for example, the discussion of themes such as abortion, animal cruelty, political corruption, etc.

Our main goals were to: (i) use linguistic knowledge from the students to get them to produce argumentative texts; (ii) identify argumentative operators in several forms of possibilities, for example, magazines, newspapers, scientific journal, propaganda, etc.; (iii) recognize authorial styles (that is, diverse points of view of determined theme) in argumentative texts; (iv) select adequate arguments to the proposition of the argumentative and dissertation text.

The didactic project's methodology was conceived in four stages and each stage was divided into three phases, which were: (a) presentation of the educational object; (b) dialogue between the disciplinary contents and its manifestation in different discursive spheres and (c) exercise and use of language. Out of the four stages, two of them were in a group and two, individual. The sequence was: 1 . individual; 2 . in a group; 3 . individual; and 4. in a group.

To clarify about how we executed the project, we present the table below, which summarizes the amount of classes used for every stage and its objectives, its didactic materials and specific actions involved. 


\begin{tabular}{|c|c|c|c|c|}
\hline \multicolumn{5}{|c|}{ TABLE 1. DIDACTIC PROJECT: EXECUTION SCHEDULE } \\
\hline STAGES & $\begin{array}{c}\text { AMOUN } \\
\text { T OF } \\
\text { CLASSES }\end{array}$ & OBJECTIVES & DIDACTIC MATERIAL & SPECIFIC ACTIONS \\
\hline $\mathbf{I}$ & 2 & $\begin{array}{l}\text { Recognizing the } \\
\text { argumentative } \\
\text { quality of the } \\
\text { concrete } \\
\text { enunciation }\end{array}$ & $\begin{array}{l}\text { Oral explanation, } \\
\text { blackboard, chalk, } \\
\text { distribution of a collection } \\
\text { of famous quotes, group } \\
\text { discussion and individual } \\
\text { production of text. }\end{array}$ & $\begin{array}{l}\text { 1. Group discussion about famous } \\
\text { quotes collected by the teacher. } \\
\text { 2. Choosing one or two quotes } \\
\text { from the collection and writing a } \\
\text { short comment on the selected } \\
\text { material. }\end{array}$ \\
\hline II & 2 & $\begin{array}{l}\text { Comprehending } \\
\text { the argumen- } \\
\text { tative quality } \\
\text { based on non- } \\
\text { verbal languages }\end{array}$ & $\begin{array}{l}\text { Oral explanation, } \\
\text { blackboard, } \\
\text { distribution of imalk, } \\
\text { representing several social } \\
\text { spheres (advertisement } \\
\text { clippings, photographs, art } \\
\text { paintings, etc.), group } \\
\text { discussion and text } \\
\text { production. }\end{array}$ & $\begin{array}{l}\text { 1. Selecting an image and } \\
\text { discussing it in its social, historical } \\
\text { and cultural meaning. } \\
\text { 2. Producing an argumentative } \\
\text { text, among a group, with a } \\
\text { dialogue. }\end{array}$ \\
\hline III & 3 & $\begin{array}{l}\text { Comprehending } \\
\text { and producing } \\
\text { arguments in } \\
\text { visual and verbal } \\
\text { materials }\end{array}$ & $\begin{array}{l}\text { Oral explanation, } \\
\text { blackboard, } \\
\text { distribution of texts } \\
\text { (newspapers, magazines, } \\
\text { scientific publications, } \\
\text { etc.) and images } \\
\text { representing several social } \\
\text { spheres (advertisement } \\
\text { clippings, photographs, art } \\
\text { paintings, etc.), group } \\
\text { discussion and individual } \\
\text { production of text. }\end{array}$ & $\begin{array}{l}\text { 1. To grasp the arguments and its } \\
\text { placement on the verbal and } \\
\text { visual material. } \\
\text { 2. Debate on linguistic structures } \\
\text { found in the argumentative text. } \\
\text { 3. Individual production of an } \\
\text { argumentative and dissertation } \\
\text { text. }\end{array}$ \\
\hline IV & 3 & $\begin{array}{l}\text { Reflecting upon } \\
\text { the types of } \\
\text { argumentation } \\
\text { and its } \\
\text { production, } \\
\text { circulation and } \\
\text { reception in the } \\
\text { contemporary } \\
\text { capitalist society }\end{array}$ & $\begin{array}{l}\text { Oral explanation, } \\
\text { blackboard, } \\
\text { distribution of texts } \\
\text { (newspapers, magazines, } \\
\text { scientific publications, } \\
\text { etc.) and images } \\
\text { representing several social } \\
\text { spheres (advertisement } \\
\text { clippings, photographs, art } \\
\text { paintings, etc.), group } \\
\text { discussion and text } \\
\text { production. }\end{array}$ & $\begin{array}{l}\text { 1. Reflection on how the } \\
\text { argumentation circulates in the } \\
\text { different spheres of human } \\
\text { agency. } \\
\text { 2. To comprehend arguments and } \\
\text { their purposes as a responsible } \\
\text { act of the individual in response } \\
\text { to his/her historical, economical } \\
\text { and cultural society. } \\
\text { 3. Group production of an } \\
\text { argumentative and dissertation } \\
\text { text that dialogues with one } \\
\text { enunciation (a poem, a chronicle, } \\
\text { an advertisement, a song, etc.) }\end{array}$ \\
\hline
\end{tabular}

This table is a schematic summary of the didactic project put into action. As such, it synthesizes the performed activities and its methodological procedures. In the next topic, we will discuss the execution of this project, as well as analyze some of the textual productions from each stage. 


\section{ANALYSIS OF STAGES AND THEIR TEXTUAL PRODUCTIONS}

In the first stage, we encouraged the student to take a critical stance about statements of strong socio-historical and cultural appeal. We selected famous quotes from great personalities of different nationalities (Confucius, Mahatma Gandhi, Bob Marley, Clarice Lispector, Carlos Drummond de Andrade, etc.) and asked the students to discuss in small groups of three to five members, about what they had understood from the statement, how they relate with the quotes and why these quotes had changed the world. This last inquiry was asked because the title of the activity was Quotes that changed the world. We thus have a provocative agent (the so-called famous quotes), an audience summoned to a discussion (students) and a dialogue mediator (teacher). These three gears should work together appropriately so that the whole process of teaching and learning occur effectively.

The specific task of this step was writing an individual comment about one or two sentences of the compilation. There is a sample below from one writing of each of the two schools - we emphasize that, as a methodological approach, we selected the title and first paragraph of each textual production, which is what we will also do on the other examples ${ }^{7}$.

\begin{tabular}{|c|c|}
\hline \multicolumn{2}{|c|}{ TABLE 2. STAGE 1} \\
\hline SCHOOL A - Student A1 & SCHOOL B - Student A2 \\
\hline $\begin{array}{l}\text { Quote: "While skin color is more important than the } \\
\text { brightness of the eyes, there will always be war." } \\
\text { Bob Marley }\end{array}$ & $\begin{array}{l}\text { Quote: "Be the change you want to see in the } \\
\text { world." } \\
\text { Mahatma Gandhi }\end{array}$ \\
\hline $\begin{array}{l}\text { It still needs an end! } \\
\text { Prejudice is more and more present in our population, } \\
\text { with prejudice in our population, with prejudice in our } \\
\text { world against afro-descendents, homosexuals and } \\
\text { lower-class, it ends up happening physical and } \\
\text { emotional aggression, we must not be satisfied only } \\
\text { because it was reduced from the past that slavery } \\
\text { existed, for example, as I said it was reduced and not } \\
\text { finished so we do not have to put the word satisfied, it } \\
\text { will only be possible when we do not hear and do not } \\
\text { see the word discrimination and prejudice in people's } \\
\text { mouths anymore, we is not obliged to accept, but to } \\
\text { respect. }\end{array}$ & $\begin{array}{l}\text { Two faces } \\
\text { It has been a long time since society started talking } \\
\text { about honesty and sincerity among individuals. } \\
\text { Since then, people's "word" lost its value. We } \\
\text { struggle so that there is more fellowship and truth } \\
\text { in the world. There is still difference and dishonesty } \\
\text { everywhere. }^{9}\end{array}$ \\
\hline
\end{tabular}

Both productions are very different, since they indicate quite different singularities and problems. Student A1 has a well-defined discursive positioning, prejudice has to end,

\footnotetext{
${ }^{7}$ Our examples selection criterion was to raffle them in the classroom before the correction of the students' productions. In these raffles, the selected students were previously informed and agreed to participate in the project as long as they were kept anonymous. All participants in this study, from both schools, signed the consent form.

${ }^{8}$ Translated from Portuguese.

${ }^{9}$ Translated from Portuguese.
}

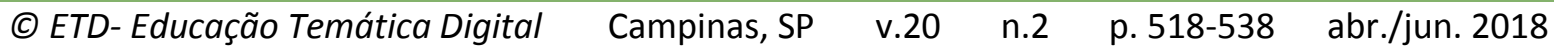


satisfactorily dialoguing with the quote by Bob Marley. However, the provision of his arguments and his organization are inadequate, which is noticeable by linguistic marks such as, for example, the repetition of sentences, the rough syntax, spelling and verbal regency mistakes (e.g. "we is"), and also for organizing the ideas as a tautological system.

Student $A 2$, on the other hand, does not link the theme of his comment to the quotes by Mahatma Gandhi successfully, thus the juxtaposed sentences cannot build a consistent and adequate line of reasoning to defend his point of view, although the sentences are grammatically well-formed.

In order to understand these linguistic and discursive occurrences, we can differentiate competence and skill. There are different definitions for the concepts of competence and skill in several spheres of human activity in which they circulate (financial market, education, world of work, etc.). According to Zabala and Arnau (2010), the dissemination of these two concepts occurred in an accelerated way and caused opinions in favor and against in the area of Education. In this text, we use the proposal of Perrenoud (1999) to understand these concepts. According to the author, competence is defined as the "ability to act effectively in a given type of situation, supported by, but not limited to, knowledge" (PERRENOUD, 1999 p.7, free translation). Therefore, it comes down to the know-how of an individual when performing certain proposed activities. The notion of skill, for the same author, is a sequence of operative modes of inductions and deductions. Thus, Perrenoud (1999) defines skill as a series of mental procedures that the individual uses to solve a real situation in which he or she needs to make a decision. From this perspective, competence can be defined as the know-how, the general knowledge that sustains and directs what the individual does. Skill is the ability to do, the specific and instrumental knowledge to perform the act.

When it comes to writing an argumentative text, competence is the ability to make a statement in which one can infer the position advocated about a controversial issue, and skill is the individual's performance in the use of language and its grammar to develop axiological and ideological positioning. In the examples discussed above, we can understand that both Student $\mathrm{A} 1$ and $\mathrm{A} 2$ have argumentative competence, but lack further development of their skills. Therefore, the focus of our teaching work was to enhance the skills of the students, because we assumed that they had argumentative competence, but not all students had developed their skills.

In the second stage, the proposal was to work with images in various social spheres to broaden the students' perception of what the text and the role of argumentation in different materials would be - something we kept doing on the other stages. We selected advertisements, film ads, cartoon scenes, paintings and other visual materials and asked that, in groups, students discussed the social, cultural and historical meaning of these images. So they discussed what a text is and its social role. At the end of the exploration of 
the meanings of a visual statement, the specific task was to write an argumentative text in a group, which would dialogue with an image to be chosen by the group. Below, there are examples of the written production of two groups, one of each school.

\begin{tabular}{|l|l|l|l|}
\hline \multicolumn{9}{|l|}{ TABLE 3. STAGE 2 } \\
\hline SCHOOOL A - GROUP I
\end{tabular}

Group I did a metaphorical reading of the image, which shows enough reflective depth to make connections between social relations and symbols. However, the writing skill of the group is out of phase, because the sentences are in disharmony among themselves: a sentence does not resume or moves forward in relation to the other. Compared to Group II, we have a critical reading of the image and it is grammatically well formed, still, the relationship between text and image was not as well linked, as it was by Group I. Therefore, we understood, along with the students, that the interpretation of an image is not restricted to the edges of its page or frame, but it may cause, as any concrete statement, a response from its beholder, as in Bakhtin (2006b).

In the third stage, we carried on with the interpretation of images and added the comprehension of texts of argumentative content of various spheres of human activity (newspapers, magazines, scientific journals, advertising material, etc.). Our strife lied on making the student infer arguments and their organization in verbal material (vocabulary selection, segmentation of the text, disposition of ideas, etc.) and in visual (color, shape, arrangement of objects, scenery, plans, purpose, etc.). By doing so, we could discuss linguistic structures and their possible executions in many genres of the discourse (announcement, advertisement, letter to the reader, argumentative chronicle, etc.). The specific task was writing individually an argumentative and dissertation text dialoguing with one of the images discussed in the classroom. Below, we present two examples, one from each school.

\footnotetext{
${ }^{10}$ The images were taken from the Internet or from magazine clippings gifted to the school library.

11 Translated from Portuguese.

${ }^{12}$ Translated from Portuguese.
}

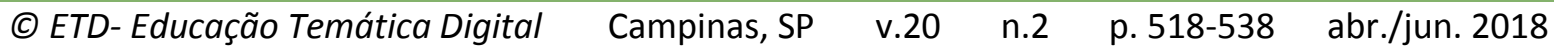




\begin{tabular}{|l|l|l|l|}
\hline \multicolumn{2}{|c|}{ TABLE 4. STAGE ${ }^{13}$} \\
\hline SCHOOL A - Student B1 & $\begin{array}{l}\text { SCHOOL B - Student B2 } \\
\text { The beauty dictatorship } \\
\text { experiencing a beauty and } \\
\text { etiquette dictatorship. } \\
\text { People are increasingly } \\
\text { vain, women have plastic } \\
\text { surgeries increasingly } \\
\text { early, children increasingly } \\
\text { consumerist and men } \\
\text { entering a world that until } \\
\text { recently was only for } \\
\text { women. }{ }^{14}\end{array}$ & $\begin{array}{l}\text { The first homes bring a } \\
\text { pattern within, a family } \\
\text { concept, and, in some cases, } \\
\text { even diversity. It is the } \\
\text { model of the home or its } \\
\text { architecture. Are they equal } \\
\text { or not? What is the meaning } \\
\text { of this? }\end{array}$ \\
\hline th
\end{tabular}

In both examples, there is an excellent connection of ideas as well as their disposition for the standard Brazilian Portuguese and the interpretation of the image was creative and responsive - more than in the previous examples. In Student B1's text, there is greater argumentative power in the discursive resource shown in the example, which exposes and implements the universe perceived by the student. In Student B2's text, there is the interrogation resource, which presupposes and requires a response, a statement about the author and the reader. Given these features, we can say that there was a breakthrough in the way the argumentative and dissertation text is built in the analyzed texts.

In the fourth and final stage, having observed the progress of each individual student and the progress of our educational project, we tried to emphasize, as a group, the uses of argumentation in our contemporary capitalist society. In order to do this, we reflected about how the argument circulates in different spheres of human activity: the television news, criminal justice, politics, etc.

Based on that, we were able to bring into discussion the purpose of the argument and how it could help to state responsive and responsible act within social spheres. From these discussions, the specific task was to produce, in a group, one argumentative and dissertation text to dialogue with a statement (a poem, a chronicle, an advertisement, a song, etc.). Below, we present two examples of the texts, one from each school.

\footnotetext{
${ }^{13}$ The images were taken from the Internet or from magazine clippings gifted to the school library.

${ }^{14}$ Translated from Portuguese.

15 Translated from Portuguese.
}

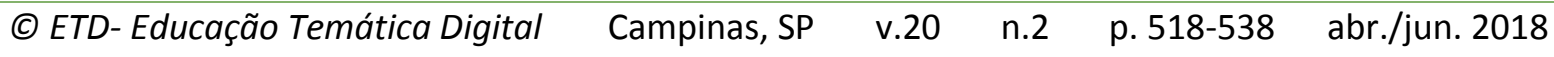




\begin{tabular}{|l|l|l|}
\hline \multicolumn{3}{|c|}{ TABLE 5. STAGE ${ }^{16}$} \\
\hline SCHOOL A - GROUP III & $\begin{array}{l}\text { The punished pregnant woman } \\
\text { Pregnant, expecting her third } \\
\text { child, a woman is surprised by } \\
\text { the arrival of a lady dressed as a } \\
\text { bride. The stranger says her } \\
\text { child's father is the pregnant } \\
\text { woman's husband. The stranger } \\
\text { is the mistress. The pregnant } \\
\text { woman sees herself in a very } \\
\text { uncomfortable situation, ends } \\
\text { up getting nervous and then } \\
\text { loses her child, causing } \\
\text { embarrassment to everyone in } \\
\text { the waiting room. Here is a } \\
\text { melodrama that can happen if } \\
\text { we continue to build } \\
\text { dysfunctional families. }{ }^{17}\end{array}$ & $\begin{array}{l}\text { Tor a long time now, dolls } \\
\text { have been a mirror for girls. } \\
\text { So that they learn to be like } \\
\text { their mothers. Thus, they } \\
\text { are brought up to take care } \\
\text { of the children, the house, } \\
\text { the husband. This social } \\
\text { control is perceived from the } \\
\text { role they play. The dolls } \\
\text { physically inspire the girls. }{ }^{18}\end{array}$ \\
\hline
\end{tabular}

Group III had a very interesting discursive strategy. It begins as a narrative text, named by the authors as "melodrama", and then, at the end of the paragraph, is linked to a moral conclusion about the situation of Brazilian families. Thus, what we learn by reading the text is that the authors were able to organize their thoughts in a dialogical way, either by hybridization of text type (descriptive narration to argumentative and dissertation) and the axiological and ideological positioning of the authors compared to the situation of families: "Here is a melodrama that can happen if we continue to build dysfunctional families."

Group IV also showed a great development of argumentative skills. The text recalls the situation of women and their social control from several angles to discuss their place in society. The theme is well illustrated with examples, the order of sentences is well organized and the responsive and responsible position of the authors is clear: "This social control is perceived from the role we play."

During these four stages, students and their teachers understood, along with the researchers, that learning can be more dynamic and dialogical. We must not silence the student or put him in front of a book as a copyist or passive reader. Our project had as a

\footnotetext{
${ }^{16}$ Even though there were many options (poem, music, editorial, etc.), most of the students from both classes (over $75 \%$ ) chose to work with images, which was a positive feedback on our work with visual materials. The images were taken from the Internet or from magazine clippings gifted to the school library.

${ }^{17}$ Translated from Portuguese.

${ }^{18}$ Translated from Portuguese.
} 
main tool the student's response and his/her responsive understanding. That was the reason why we insisted on group activities so that the dialogue could be uninterrupted. All the material produced and circulated in the classroom should have a life of its own in the relationships built among the teacher, the student and the knowledge object. With this in mind, we have brought the student's life to the classroom and he/she gave birth to his/her texts.

In the first two stages, it was notorious in both individual and group activities, that the students were out of phase concerning the ability to write an argumentative text in which he/she could make his/her point in a consistent and appropriate way according to the standard Brazilian Portuguese and to his/her own axiological and ideological positioning. In order to change this situation, we discussed the dialogical relations involving disciplinary content and writing itself. Considering this, we put into our teaching practice the Bakhtinian posture:

Understanding repeatable elements and the unrepeatable whole. Recognizing and encountering the new and unfamiliar. Both of these aspects (recognition of the repeated and discovery of the new) should merge inseparably in the living act of understanding. [...] (BAKHTIN, 2006d, p. 378, free translation).

Therefore, our proposal was to go beyond what was already known through discussion and dialogue, to awaken the new on our students and teachers. In addition, the result was very satisfactory, which we will prove in our closing remarks.

\section{CLOSING REMARKS}

The word project has its etymological origin, projectum, in the composition of the Latin prefix pro, which means "forward", with jacere, which means "launch, throw". Thus, to make a project means to throw oneself ahead. That was our goal: to throw ourselves forward to achieve true quality education.

The schools we visited were transformed. The project stimulated a more lively and dynamic interaction among teachers, students and knowledge objects. This positively influenced the assessment of students, teachers and the institutional structure itself. This progress can be measured quantitatively and qualitatively.

School A had a great increase in IDESP ${ }^{19}$ scores, if we compare the scores of the Portuguese and overall grades in the years of 2013, 2014 and 2015 from students of $3^{\text {rd }}$ year of High School. In both 2013 and 2015, the school had not achieved the State goal and their distribution by level of performance was zeroed in advanced level and below $10 \%$ at the

\footnotetext{
${ }^{19}$ "The IDESP is an indicator that evaluates the quality of the school. In this review, it is considered that a good school is that in which most of the students grasp the skills and abilities required for its grade, over the ideal period - the school year. For this reason, the IDESP consists of two criteria: the performance of students in proficiency official examinations (how much they learned) and relation between age and school grade (how soon they learned)." (GOVERNO DO ESTADO DE SÃO PAULO, 2011, p 1).
}

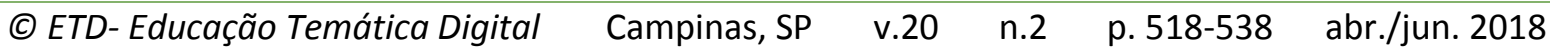


appropriate level. In 2015, the school achieved $120 \%$ of the government goal and students' performance in suitable and advanced levels was $29.73 \%$ and $2.7 \%$ respectively. School B also showed improvement. In ENEM ${ }^{20}$, if we compare the years 2013, 2014 and 2015, the school achieved an overall growth of 3.5\% over the years 2014 and 2015 . Note that from 2013 to 2014 the school had decreased their overall performance. These numbers are the quantitative and qualitative evidences, we could see throughout the previous topic that, at each stage, the produced text earned in responsiveness, creativity, organization and adaptation to the educated norms of the Brazilian Portuguese.

As we can observe from the analysis of the data, the Bakhtinian philosophy is the most adequate one for the teaching and learning of argumentative texts, mainly within the context of Portuguese Language. We stand up for the following arguments. First, it is a theoretical proposal that allows the participation and intervention of different areas of human knowledge (history, literature, communication, sociology, etc.). Second, it is a model of investigation of human practices in their actual conditions of event. Third, it is a theory under construction, since it is open to the potentialities of the responsible and responsive act of each individual.

Therefore, our project in the schools we visited is evidence that it is possible to unite teaching theory and practice, especially when we realize that being a teacher does not mean to stop being a student, but to remain a lifelong learner. That is why we believe that education and training are allies of both Order and Progress, the motto in the Brazilian national flag. Thus, the didactic project we presented, analyzed and validated here is not only a mere intervention in the school environment, but it is the recognition that schools and universities cannot be divorced. Instead, they must go together so that our flag always remains upright.

\section{ACKNOWLEDGEMENT ${ }^{\mathrm{i}}$}

Grammar review of translation by Prof. Dr. Paul Jeremy Turner.

\section{REFERENCES}

BAKHTIN, Mikhail Mikhailovitch. Speech genres and other late essays. Translation by Vern W. McGee. Austin: University of Texas, 1986.

\footnotetext{
20 "Created in 1998, the High School National Exam (Enem) aims to assess student performance at the end of high school. Participation in the exam is allowed to students who are completing or who have completed high school in previous years. Enem is used as selection criteria for students who intend to apply for a scholarship at the University for All Program (ProUni). In addition, about 500 universities already use the result as a selection criterion, either complementing or replacing their entrance exam." (MINISTÉRIO DA EDUCAÇÃO, 2014).
} 
BAKHTIN, Mikhail Mikhailovitch. Gêneros do discurso. In: BAKHTIN, Mikhail Mikhailovitch. Estética da criação verbal. Translation by Paulo Bezerra. 4th ed. São Paulo, SP: Martins Fontes, 2006a, p. 261-306.

BAKHTIN, Mikhail Mikhailovitch. O autor e o personagem na atividade estética. In: BAKHTIN, Mikhail Mikhailovitch. Estética da criação verbal. Translation by Paulo Bezerra. 4th ed. São Paulo, SP: Martins Fontes. 2006b, p. 3-186.

BAKHTIN, Mikhail Mikhailovitch. Metodologia das ciências humanas. In: BAKHTIN, Mikhail Mikhailovitch. Estética da criação verbal. Translation by Paulo Bezerra. 4th ed. São Paulo, SP: Martins Fontes. 2006c, p. 393-410.

BAKHTIN, Mikhail Mikhailovitch. Apontamentos de 1970-1971. In: BAKHTIN, Mikhail Mikhailovitch. Estética da criação verbal. Translation by Paulo Bezerra. 4th ed. São Paulo, SP: Martins Fontes, 2006d, p. 367-392.

BAKHTIN, Mikhail Mikhailovitch. Para uma filosofia do ato responsável. Translation by Valdemir Miotello and Carlos Alberto Faraco. São Carlos: Pedro \& João, 2010.

BAKHTIN, Mikhail Mikhailovitch. Questões de estilística no ensino da língua. Translation by Sheila Grillo and Ekaterina Vólkova Américo. São Paulo,SP: Ed. 34, 2013.

BARBOSA, Jaqueline. Trabalhando com os gêneros do discurso: uma perspectiva enunciativa para o ensino de língua portuguesa. PhD. Thesis (Doctoral Research in Applied Linguistics and Language Teaching) Postgraduate Studies Program in Applied Linguistics and Language Studies (LAEL). São Paulo, SP: Pontifícia Universidade Católica de São Paulo, 2001.

BRAIT, Brait; ROJO, Roxane. Gêneros: artimanhas do texto e do discurso. São Paulo, SP: Escolas Associadas, 2003.

BRASIL. Orientações curriculares para o ensino médio. Vol. 1. Linguagens, códigos e suas tecnologias / Secretaria de Educação Básica. Brasília, DF: Ministério da Educação, Secretaria de Educação Básica, 2006.

BRASIL. Parâmetros Curriculares Nacionais. (Ensino Médio). Brasília, DF: Ministério da Educação, Secretaria de Educação Básica, 2000.

COELHO, Patrícia Margarida Farias; COSTA, Marcos Rogério Martins. Os gêneros do discurso no espaço escolar: da teoria à prática pedagógica. Revista Querubim, Rio de Janeiro, ano 9, n.19, p. 72-77, 2013.

COSTA, Marcos Rogério Martins; COELHO, Patrícia Margarida Farias. A produção escrita na sala de aula: trabalhando com textos. Intersecções. Jundiaí, 2013. v. 6, p. 19-39.

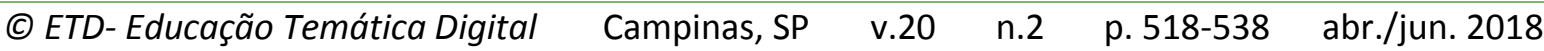


FREITAS, Maria Teresa de Assunção. Bakhtin e a psicologia. In: FARACO, Carlos Alberto; TEZZA, Cristovão; CASTRO, Gilberto de. (Orgs.). Diálogos com Bakhtin. Curitiba-PR: Ed. da UFPR, 1996, p. p. 141-160.

GOVERNO DO ESTADO DE SÃO PAULO. Programa de qualidade da escola - Norma técnica. São Paulo-SP: Secretaria do Estado da Educação, 2011.

MINISTÉRIO DA EDUCAÇÃO. Apresentação do ENEM. 2014. Disponível em: http://portal.mec.gov.br/index.php?option=com content\&view=article\&id=183\&ltemid=31 0>. Acesso em: 12 abr. 2017.

PERRENOUD, Phillipe. Avaliação da excelência à regulação das aprendizagens: entre duas lógicas. Translation by Patrícia Ramos. Porto Alegre: Artmed, 1999.

PLATIN, Christian L'Argumentation. Paris: Èditions du Seuil, 1996.

PONZIO, Augusto. A concepção bakhtiniana do ato como dar um passo. In: BAKHTIN, Mikhail Mikhailovitch. Para uma filosofia do ato responsável. Translation by Vlademir Miotello and Carlos Alberto Faraco. São Carlos: Pedro \& João, 2010.

ROJO, Roxane. A prática de linguagem em sala de aula: praticando os PCNs. São Paulo-SP: EDUC; Campinas: Mercado de Letras, 2000.

SÃO PAULO (Estado). Secretária da Educação. Língua Portuguesa: Linguagens, códigos e suas tecnologias. 3a série do Ensino Médio. 3o e 4ำ bimestres. São Paulo: Secretária da Educação, 2012.

SCHNEUWLY, Bernard. Le travail enseignant. In: SCHNEUWLY, Bernard; DOLZ, Joaquim. (Orgs.). Des objets enseignés en classe de français - Le travail de l'enseignant sur la rédaction de texts argumentatifs et sur la subordonnée relative. Rennes : Presses Universitaires de Rennes, 2009. p. 29-43.

VOLOSHINOV, Valentin Nikolaevic. Marxism and the philosophy of language. Translation by Ladislav Matejka e I. R. Titunik. Cambridge/ Massachusetts/ London: Harvard Univ., 1986.

ZABALA, Antoni; ARNAU, Laia. Como aprender e ensinar competências. Translation by Carlos Henrique. Lucas Lima. Porto Alegre: ArtMed, 2010.

\footnotetext{
' Revisão gramatical do texto sob a responsabilidade de: Prof. Rafael Libório de Souza. E-mail: rafael.liborio.souza@usp.br
} 